\title{
Does Uniform Wage Decline the Welfare in a Budget-Constraint Mixed Market?
}

\author{
Ting-Chung Tsai ${ }^{1}$, Kuang-Feng Cheng1, Chuchuan Hsu ${ }^{2 *}$, Chienshu Tsai ${ }^{3}$, Chienchih Chen ${ }^{4}$, \\ Jenyao Lee ${ }^{*}$
}

\footnotetext{
${ }^{1}$ Department of International Business, National Kaohsiung University of Sciences and Technology, Taiwan ${ }^{2}$ Department of Marketing and Logistics Management, Yu Da University of Science and Technology, Taiwan ${ }^{3}$ Department of Tourism Management, Kao Yuan University, Taiwan ${ }^{4}$ School of Management and Economics, Kunming University of Science and Technology, Kunming, China Email: *edison9@ydu.edu.tw
}

How to cite this paper: Tsai, T.-C., Cheng, K.-F., Hsu, C., Tsai, C., Chen, C. and Lee, J. (2019) Does Uniform Wage Decline the Welfare in a Budget-Constraint Mixed Market? Modern Economy, 10, 474-483. https://doi.org/10.4236/me.2019.102032

Received: January 16, 2019

Accepted: February 15, 2019

Published: February 18, 2019

Copyright $\odot 2019$ by author(s) and Scientific Research Publishing Inc. This work is licensed under the Creative Commons Attribution International License (CC BY 4.0).

http://creativecommons.org/licenses/by/4.0/

\begin{abstract}
In this paper, we explore the influence of union structure and wage pricing strategies on the welfare under a mixed oligopoly which has a public firm with budget constraint. We showed that, the total utilities of the decentralized unions are higher than the utility of the centralized union under mixed duopoly if the centralized union charges a uniform wage and the productivity difference is large. The government should restrict the centralized union formed by the public and the private firm to charge discriminatory wages, and to avoid the improper use of the monopoly power of the labour union.
\end{abstract}

\section{Keywords}

Decentralised Unions, Centralised Union, Productivity Difference, Privatization

\section{Introduction}

Much empirical evidence suggests that many countries are moving towards more decentralized unionization structure, which is not consistent with the theoretical result: if workers are close substitutes, they are better off under a centralized union than under decentralized unions ${ }^{1}$. In Taiwan, even though the decentralized unions prevail for most of the industry, but for those industries such as energy, aviation and banking in which the nationalized firm (SOE) starts and was the monopolist, the centralized (united) union remains intact because the politi${ }^{1}$ Under decentralized unions, wage is set between a firm and the firm-specific labour union, while under a centralized union, an industry-wide union negotiates wage for the entire industry. See, for example, Horn and Wolinsky [1], and Davidson [2]. 
cal-power consideration of the central government when the firms is widely dispersed in different regions with uneven development. For example, the centralized union is formed between a nationalized firm, China Airlines (Taiwan) and a private firm, the Eva Air. The centralized union across the public and the private sector unions for the aviation staffs are under operation and are very powerful when it negotiated with the government in a mixed market.

A craft union is our concern in this paper which is organized by the same labour position of the people together. Taoyuan City Flight Attendant Craft union is a labour organization designed for the "flight attendant" in which China Airlines, Eva Air, TransAsia Airways, Far Eastern Air Transport and other airline flight attendants also can join. In the actual operation of company union, the wage and benefit may not be the same between Eva Air and China Airlines; therefore, it may result in discriminatory wages for different unions.

The welfare analysis of the union structure, labour productivity differences, and wage pricing is important. It contributes to the important policy value of the government in the formulation of industrial regulation and market structure. The rest of the paper is organized as follows. Review of relevant literature is given in Section 2. Section 3 presents the model setting. Section 4 examines the influence of union structures on social welfare. Section 5 concludes.

\section{Literature Review}

It has been recognized that a public firm may not earn positive profit in mixed oligopoly theory. Bennett and La Manna [3] establish an irrelevance result in a closed economy with budget constraint imposing on the public firm and allowing free private entry: whenever a mixed oligopoly is viable, then aggregate output, aggregate costs and welfare are the same, without or with the public firm that is subject to a break-even constraint. The issue of budget constraint is being raised in a different context of a mixed market ${ }^{2}$. Choi [6] considers the budget-constraint problem in a unionized mixed oligopoly where the government decides whether or not to impose a budget on a public firm, assuming that the public firm is less efficient than private firms. He finds that imposing budget constraints on a public firm is the preferred choice because of the welfare-improving effect, and the wage levels of the public firm can be lower or higher than those of private firms depending upon the degree of inefficiency. The above results differ from Ishida and Matsushima's [7] findings that in a unionized mixed duopoly, tighting budget constraints can enhance social welfare when the public firm is as efficient as private firms. However, the above two papers did not consider an important issue: should the government restrict the centralized union formed by the public and the private firm to charge discriminatory wages ${ }^{3}$ ?

${ }^{2}$ See De Fraja and Delbono [4] for the specification of the public firm in mixed oligopoly and De Fraja and Delbono [5] for the general review of mixed oligopoly models.

${ }^{3}$ Low productivity of the public firm results from two factors, one is its low operating efficiency and another one is seldom mentioned for the policies burden which decreases the incentives resulting moral hazard, and shirking on work efforts and suffering negative profit. 
When the government restrict the union structure, the power of unions is influential. Thus, ignoring the power of unions, no matter centralized or decentralized, can lead to biased analytical results. Although, the research on privatization policy is numerous (See [4] [5] [8] and thereafter), the implications of unionization structure on whether the public firm should be privatized was seldom thoroughly analyzed ${ }^{4}$. Liu and Lo [12] study the structure of union-wage Nash bargaining and it's implication on privatization, and show that centralized bargaining is better than decentralize bargaining for welfare improvement. But they do not consider the influence of labour productivity difference, budget constraint of public firm, and discriminatory wages.

In this paper, we explore the influence of union structure and wage pricing strategies on the welfare under a mixed oligopoly which has a public firm with budget constraint. We showed that, the total utilities of the decentralized unions are higher than the utility of the centralized union under mixed duopoly if the centralized union charges a uniform wage and the productivity difference is large.

\section{The Model}

Consider an economy with two final goods producers, firms 1 and 2. These firms produce a homogeneous product. We assume that the inverse market demand function for the product is $p=1-q$, where $p$ is price and $q=q_{1}+q_{2}$ is the total output. We also assume that both firms require only workers to produce the product. Assume that firm 1 requires one worker to produce one unit of output, while firm 2 requires $\lambda$ workers to produce one unit of output, where $\lambda>1^{5}$. The difference in labour coefficients, which may be the outcome of a labour saving innovation by firm 1, as in Mukherjee and Pennings [18], creates different labour productivities in the firms. The labour productivity in firm 1 is 1 and in firm 2 , it is $\frac{1}{\lambda}$.

We assume that the firms hire workers from labour unions. We will consider two types of labour unions:

1) Decentralized unions, where the firm-specific labour unions set wages for respective firms.

2) A centralized union, where an industry-wide labour union sets wage for all firms. We will consider both uniform and discriminatory wages under a central${ }^{4}$ For literature on union bargaining in mixed oligopoly, see De Fraja [9], Willner [10], Gronblom and Willner [11], Ishida and Matsushima [7] and Choi [6].

${ }^{5}$ The public firm has a lower labour productivity which may highly due to shirking behavior in the large-size public sector. Hence, public firms are less efficient than private firms. Many empirical works do not support this view (and many other papers do support this view). Using constant marginal costs and assuming cost differences between public and private firms can be found in Mujumdar and Pal [13], Pal [14], Matsumura [15], and Matsumura and Ogawa [16]. Note that the linearly increasing marginal cost function is more general, which is used in De Fraja and Delbono [4], and Bárcena-Ruiz and Garzón [17], for the specification of linearly increasing marginal cost function under mixed oligopoly.

${ }^{6}$ See Mukherjee [19], Mukherjee et al. [20], and Mukherjee and Wang [21] using the same parameter for labour productivity difference. 
ized union. Following Yoshida [22], it can be argued that a centralized union prefers discriminatory wages than a uniform wage. However, government regulation may induce a centralized union to set a uniform wage [23] [24] [25].

In a mixed economy with two final goods producers, private firm 1 and public firm 2 producing a homogeneous product, the private firm as usual maximizes its profit. The public firm concerns about social welfare

$S W=C S+\pi_{1}+\pi_{2}+u_{1}+u_{2}$ but subject to the nonnegative profit constraint. $C S$ is the consumer surplus, $C S=q^{2} / 2$.

We consider the following game. At stage 1, the unions set wage. At stage 2, firms 1 and 2 choose the outputs simultaneously, and the profits are realised. We solve the game through backward induction.

When there is a union in each firm, the wage is determined by the bargain result between union and its corresponding firm. Let the reserved wage be $\bar{w}$, then the utility functions of each union are

$$
u_{i}=\left(w_{i}-\bar{w}\right)^{\theta} l_{i}, \quad i=1,2
$$

The importance a union attaches to the wage is assigned as $\theta$ (See Haucap and Wey [6] [26]). $\theta$ denotes the preference of the union. When $\theta=1$, the unions put equal weights on the wages and the numbers of the employment; when $\theta=0$, the unions care about the numbers of the employment only. In recent year, craft unions are negotiating with enterprises, and most of the disputes are focused on labour conditions, and therefore can be regarded as equal importance. To be able to focus on the purpose of this paper, the following assumptions are made: $\theta=1$, and the reservation wage of the workers is normalised to zero.

First, determine the equilibrium outputs of the firms when the firm $i$ faces the wage rate $w_{i}, i=1,2$. Firms 1 and 2 maximise $\pi_{1}=\left(1-q-w_{1}\right) q_{1}$ and $S W$ subject to budget constraint $\pi_{2} \geq 0$ to determine $q_{1}$ and $q_{2}$ respectively. The public firm 2's maximized problem is

$$
\max _{q_{2}} S W
$$

s.t. $\pi_{2}=\left(p-\lambda w_{2}\right) q_{2} \geq 0$.

Denoting $\alpha$ as the multiplier of the budget constraint, the Lagrangian equation can be written as

$$
L=S W+\alpha \pi_{2}
$$

Taking $w_{i}$ as given, the first-order conditions are given by

$$
\begin{gathered}
\frac{\partial L}{\partial q_{2}}=(1+\alpha)\left(1-q_{1}\right)-(1+2 \alpha) q_{2}-(1+\alpha) \lambda w_{2}+\lambda w_{2}=0 \\
\frac{\partial L}{\partial \alpha} \alpha=\alpha\left(1-q_{1}-q_{2}-\lambda w_{2}\right) q_{2}=0
\end{gathered}
$$

The first-order condition for the private firm is given by

$$
\frac{\partial \pi_{1}}{\partial q_{1}}=1-2 q_{1}-q_{2}-w_{1}=0
$$


Solving the first-order conditions (2), (3) and (4), we obtain the equilibrium outputs which are

$$
q_{1}^{*}=\lambda w_{2}-w_{1}, \quad q_{2}^{*}=1+w_{1}-2 \lambda w_{2}, \text { and } \alpha^{*}=\frac{\lambda w_{2}}{q_{2}^{*}}>0^{7}
$$

Now determine the wages set by the unions. We consider the right-to-manage model of labour union, as in Haucap and Wey [26] and Mukherjee [27], to name a few ${ }^{8}$. We assume that the unions determine wage to maximise their utilities and the firms hire workers according to their needs. To prove our result in the simplest way, we follow, e.g. Haucap and Wey [26] and Mukherjee [27], to assume that the unions have full bargaining power.

\section{Unionization Structures and Welfare}

Lemma 1: In the decentralized unions scenario, the equilibrium wages are $w_{1}^{M, d}=\frac{1}{7}$ and $w_{2}^{M, d}=\frac{2}{7 \lambda}$, where the $M$ on superscript denotes the case of mixed duopoly. The equilibrium utilities of the unions are $u_{1}^{M, d}=\frac{1}{49}$ and $u_{2}^{M, d}=\frac{8}{49}$. The output, consumer surplus and the social welfare are $q_{1}^{M, d}=\frac{1}{7}$, $q_{2}^{M, d}=\frac{4}{7}, C S^{M, d}=\frac{25}{98}$ and $S W^{M, d}=\frac{45}{98}$.

Next, we then consider a centralized union. If the centralized union charges discriminatory wages, it determines $w_{1}$ and $w_{2}$ to maximise $U^{c, d}=u_{1}^{c, d}+u_{2}^{c, d}=\lambda w_{2}\left(1+2 w_{1}-2 \lambda w_{2}\right)-w_{1}^{2}$. We have following lemma immediately.

Lemma 2: In the centralized unions scenario with discriminatory wages, the equilibrium wages are $w_{1}^{M, c, d}=\frac{1}{2}$ and $w_{2}^{M, c, d}=\frac{1}{2 \lambda}$. The equilibrium utility of the centralized union is $U^{M, c, d}=\frac{1}{4}$. The output, consumer surplus and the social welfare are $q_{1}^{M, c, d}=0, q_{2}^{M, c, d}=\frac{1}{2}, C S^{M, c, d}=\frac{1}{8}$ and $S W^{M, c, d}=\frac{3}{8}$.

With binding budget constraint, the profit will be zero for the public firm and the union in the public firm will gain more rent accordingly 9 . The centralized union charges discriminatory wages and because the low productivity is for the public firm, the union will employ more workers and force the private firm to close the shop in order to gain more rent. Under such circumstance, the utility of the centralized union is higher than the decentralized unions, but the social ${ }^{7}$ It means that $\pi_{2}^{*}=0$, and the budget constraint is binding. If we do not impose the zero profit condition for the public firm, the public firm's production decision may lead to negative profit. ${ }^{8}$ The "efficient bargaining" model, which stipulates that the firms and the unions bargain over wages and employment, is an alternative to the right-to-manage model. See, Layard et al. [28] for arguments in favour of the right-to-manage models.

${ }^{9} \mathrm{We}$ appreciate the referees pointed out that this result is based on the assumption that the union has full bargaining power. 
welfare comparison is the opposite.

If the centralized union charges a uniform wage, i.e. $w_{1}=w_{2}=w$, it determines $w$ to maximise $U^{c, u}=u_{1}^{c, u}+u_{2}^{c, u}=w[\lambda-w(1+2(\lambda-1) \lambda)]$. We have following lemma immediately.

Lemma 3: In the centralized unions scenario with uniform wage, the equilibrium wage is $w^{M, c, u}=\frac{\lambda}{2+4(\lambda-1) \lambda}$ and the equilibrium utility of the union is $U^{M, c, u}=\frac{\lambda^{2}}{4+8(\lambda-1) \lambda}$. The output, consumer surplus and the social welfare are $q_{1}^{M, c, u}=\frac{(\lambda-1) \lambda}{2+4(\lambda-1) \lambda}, \quad q_{2}^{M, c, u}=\frac{2+\lambda(2 \lambda-3)}{2+4(\lambda-1) \lambda}, \quad C^{M, c, u}=\frac{(2+\lambda(3 \lambda-4))^{2}}{8(1+2(\lambda-1) \lambda)^{2}}$ and $S W^{M, c, u}=\frac{(2+\lambda(3 \lambda-4))(2+\lambda(5 \lambda-4))}{8(1+2(\lambda-1) \lambda)^{2}}$.

With binding budget constraint, the profit will be zero for the public firm and the union in the public firm will gain more rent accordingly. But when the centralized union charges uniform wage, $w^{M, c, u}=\frac{\lambda}{2+4(\lambda-1) \lambda}$, which is higher than the wage charged by $u_{2}$ under decentralized unions, $w_{2}^{M, d}=\frac{2}{7 \lambda}{ }^{10}$. Uniform wage may not be higher than the discriminatory wages charged by the private union which is influenced by $\lambda$. We immediately have the following lemma.

Propostion 1: In mixed duopoly, the total utilities of the decentralized unions are higher than the utility of the centralized union under mixed duopoly if the centralized union charges a uniform wage and the productivity difference is large.

Proof: If the centralized union charges discriminatory wages, we derive that the utility of the centralized union, which is $U^{M, c, d}=\frac{1}{4}$, is higher than the total utilities of the decentralized unions, which is $u_{1}^{M, d}+u_{2}^{M, d}=\frac{9}{49}$. If the centralized union charges a uniform wage, we derive that the utility of the centralized union, i.e. $U^{M, c, u}=\frac{\lambda^{2}}{4+8(\lambda-1) \lambda}$, is higher (lower) than the total utilities of the decentralized unions, which is $u_{1}^{M, d}+u_{2}^{M, d}=\frac{9}{49}$ if $\lambda \in[1,2.5058$ (approx.) $]$ $(\lambda \in[2.5058, \infty))$.

The reasoning for the above result is provided as follows. If the centralized union charges discriminatory wages, the equilibrium wages are $w_{1}^{M, c, d}=\frac{1}{2}$ and $w_{2}^{M, c, d}=\frac{1}{2 \lambda}$, which are higher than the equilibrium wages under decentralized ${ }^{10} w^{M, c, u}>w_{2}^{M, d}$ if $\lambda<7.464$. 
unions, i.e. $w_{1}^{M, d}=\frac{1}{7}$ and $w_{2}^{M, d}=\frac{2}{7 \lambda}$. If the centralized union charges discriminatory wages, it internalises (indirect) competition between the decentralized unions and also has full flexibility in charging different wages to different firms, thus creating higher union utility under a centralized union than under decentralized unions.

If the centralized union charges a uniform wage, on the one hand, it internalises competition between the decentralized unions, but on the other hand, the uniformity rule restricts rent extraction by the centralized union. The uniform wage charged by the centralized union, $w^{M, c, u}=\frac{\lambda}{2+4(\lambda-1) \lambda}$, which is higher (lower) than the wage charged by $u_{2}$ under decentralized unions, which is $w_{2}^{M, d}=\frac{2}{7 \lambda}$, if $\lambda \in[1,7.464$ (approx.) $](\lambda \in[7.464, \infty))$. However, due to the restriction created by the uniformity rule under the centralized unionization, the centralized wage increases (reduces) the wage charged by $u_{1}$ under decentralized unions, which is $w_{1}^{M, d}=\frac{1}{7}$, if $\lambda \in[1,2.554$ (approx.) $] \quad(\lambda \in[2.554, \infty))$.

This reduction in the unionised wage under a centralized union compared to decentralized unions is responsible for reducing the union utility under a centralized union than under decentralized unions. That is, when there is a large difference on labour productivity $(\lambda>7.464), w^{M, c, u}<w_{2}^{M, d}<w_{1}^{M, d}$; when the difference on labour productivity is moderate $(2.554<\lambda<7.464)$, $w_{2}^{M, d}<w^{M, c, u}<w_{1}^{M, d}$, and when $(2<\lambda<2.554), \quad w_{2}^{M, d}<w_{1}^{M, d}<w^{M, c, u}$; but when the difference on labour productivity is small $(1<\lambda<2)$, $w_{1}^{M, d}<w_{2}^{M, d}<w^{M, c, u}$ which is consistent with the theoretical result even in mixed duopoly: if workers are close substitutes, they are better off under a centralized union than under decentralized unions.

We then find the consumer surplus and the social welfare under three different scenarios. If the centralized union charges discriminatory wages, we derive that the consumer surplus $C S^{M, c, d}=\frac{1}{8}$ and the social welfare level, $C S^{M, c, d}=\frac{1}{8} S W^{M, c, d}=\frac{3}{8}$, which is lower than the consumer surplus and the social welfare level of the decentralized unions, $C S^{M, d}=\frac{25}{98}, S W^{M, d}=\frac{45}{98}$. If the centralized union charges a uniform wage, we derive that the consumer surplus and the social welfare level, i.e. $C S^{M, c, u}=\frac{(2+\lambda(3 \lambda-4))^{2}}{8(1+2(\lambda-1) \lambda)^{2}}$ and $S W^{M, c, u}=\frac{(2+\lambda(3 \lambda-4))(2+\lambda(5 \lambda-4))}{8(1+2(\lambda-1) \lambda)^{2}}$, is lower (higher) than the consumer surplus and the social welfare level of the decentralized unions, which are $C S^{M, d}=\frac{25}{98}$ and $S W^{M, d}=\frac{45}{98} \quad$ if $\quad \lambda \in[1,7.464($ approx. $)] \quad(\lambda \in[7.464, \infty))$. 
On the other hand, the consumer surplus and the social welfare level, $C S^{M, c, u}=\frac{(2+\lambda(3 \lambda-4))^{2}}{8(1+2(\lambda-1) \lambda)^{2}}$ and $S W^{M, c, u}=\frac{(2+\lambda(3 \lambda-4))(2+\lambda(5 \lambda-4))}{8(1+2(\lambda-1) \lambda)^{2}}$, is always higher than the consumer surplus and the social welfare level of the centralized union charges discriminatory wages, $C S^{M, c, d}=\frac{1}{8}$ and $S W^{M, c, d}=\frac{3}{8}$.

That is, when there a large difference on labour productivity $(\lambda>7.464)$, $C S^{M, c, d}<C S^{M, d}<C S^{M, c, u}$ and $S W^{M, c, d}<S W^{M, d}<S W^{M, c, u}$; when the difference on labour productivity is from small to moderate $(1<\lambda<7.464)$, $C S^{M, c, d}<C S^{M, c, u}<C S^{M, d}$ and $S W^{M, c, d}<S W^{M, c, u}<S W^{M, d}$.

From the wage setting structure and union utility comparison stated above, the policy implication is that the government should restrict the centralized union formed by the public and the private firm to charge discriminatory wages to avoid the improper use of the monopoly power of the labour union.

\section{Conclusion}

In this paper, we explore the influence of union structure and wage pricing strategies on the welfare under a mixed oligopoly which has a public firm with budget constraint. We showed that, the total utilities of the decentralized unions are higher than the utility of the centralized union under mixed duopoly if the centralized union charges a uniform wage and the productivity difference is large. The government should restrict the centralized union formed by the public and the private firm to charge discriminatory wages. As far as the government is concerned, it should be avoided to give centralized unions excessive bargaining power, to avoid the improper use of the monopoly power of the labour union.

\section{Conflicts of Interest}

The authors declare no conflicts of interest regarding the publication of this paper.

\section{References}

[1] Horn, H. and Wolinsky, A. (1988) Bilateral Monopolies and Incentives for Merger. Rand Journal of Economics, 19, 408-419. https://doi.org/10.2307/2555664

[2] Davidson, C. (1988) Multiunit Bargaining in Oligopolistic Industries. Journal of Labor Economics, 6, 397-422. https://doi.org/10.1086/298189

[3] Bennett, J. and La Manna, M. (2012) Mixed Oligopoly, Public Firm Behavior, and Free Private Entry. Economics Letters, 117, 767-769. https://doi.org/10.1016/j.econlet.2012.08.025

[4] De Fraja, G. and Delbono, F. (1989) Alternative Strategies of a Public Enterprise in Oligopoly. Oxford Economic Papers, 41, 302-311. https://doi.org/10.1093/oxfordjournals.oep.a041896

[5] De Fraja, G. and Delbono, F. (1990) Game Theoretic Models of Mixed Oligopoly. Journal of Economic Surveys, 4, 1-17. 
https://doi.org/10.1111/j.1467-6419.1990.tb00077.x

[6] Choi, K. 2011) Strategic Budget Constraints in a Unionized Mixed Oligopoly. Japanese Economic Review, 62, 504-516. https://doi.org/10.1111/j.1468-5876.2010.00521.x

[7] Ishida, J. and Matsushima, N. (2009) Should Civil Servants Be Restricted in Wage Bargaining? A Mixed-Duopoly Approach. Journal of Public Economics, 93, 634-646. https://doi.org/10.1016/j.jpubeco.2008.11.004

[8] Matsumura, T. (1998) Partial Privatization in Mixed Duopoly. Journal of Public Economics, 70, 473-483. https://doi.org/10.1016/S0047-2727(98)00051-6

[9] De Fraja, G. (1993) Union and Wages in Public and Private Firms: A Game Theoretic Analysis. Oxford Economic Papers, 45, 457-469. https://doi.org/10.1093/oxfordjournals.oep.a042102

[10] Willner, J. (1999) Policy Objectives and Performance in a Mixed Market with Bargaining. International Journal of Industrial Organization, 17, 137-145. https://doi.org/10.1016/S0167-7187(97)00036-2

[11] Gronblom, S. and Willner, J. (2008) Privatization and Liberalization: Costs and Benefits in the Presence of Wage-Bargaining. Annals of Public and Cooperative Economics, 79, 133-160. https://doi.org/10.1111/j.1467-8292.2007.00356.x

[12] Liu, T.G. and Lo, L.F. (2007) Union-Wage Bargaining and Privatization in Mixed Duopoly. Asia-Pacific Economic and Management Review, 10, 1-22.

[13] Mujumdar, S. and Pal, D. (1998) Effects of Indirect Taxation in a Mixed Oligopoly. Economics Letter, 58, 199-204. https://doi.org/10.1016/S0165-1765(97)00264-4

[14] Pal, D. (1998) Endogenous Timing in a Mixed Oligopoly. Economics Letter, 61, 181-185. https://doi.org/10.1016/S0165-1765(97)00264-4

[15] Matsumura, T. (2003) Stackelberg Mixed Duopoly with a Foreign Competitor. Bulletin of Economic Research, 55, 275-287. https://doi.org/10.1111/1467-8586.00175

[16] Matsumura, T. and Ogawa, A. (2010) On the Robustness of Private Leadership in Mixed Duopoly. Australian Economic Papers, 49, 149-160. https://doi.org/10.1111/j.1467-8454.2010.00393.x

[17] Bárcena-Ruiz, J.C. and Garzón, M.B. (2006) Mixed Oligopoly and Environmental Policy. Spanish Economic Review, 8, 139-160. https://doi.org/10.1007/s10108-006-9006-y

[18] Mukherjee, A. and Pennings, E. (2011) Unionization Structure, Licensing and Innovation. International Journal of Industrial Organization, 29, 232-241. https://doi.org/10.1016/j.ijindorg.2010.06.001

[19] Mukherjee, A. (2010) Licensing in a Vertical Structure. In: Everett, B.A. and Trijillo, N.L., Eds., Technology Transfer and Intellectual Property Issues, Nova Science Publishers, Hauppauge.

[20] Mukherjee, A., Broll, U. and Mukherjee, S. (2012) Bertrand versus Cournot Competition in a Vertical Structure: A Note. The Manchester School, 80, 545-559. https://doi.org/10.1111/j.1467-9957.2012.02228.x

[21] Mukherjee, A. and Wang, L.F.S. (2013) Labor Union, Entry and Consumer Welfare. Economics Letters, 120, 603-605. https://doi.org/10.1016/j.econlet.2013.06.032

[22] Yoshida, Y. (2000) Third-Degree Price Discrimination in Input Market. American Economic Review, 90, 240-246. https://doi.org/10.1257/aer.90.1.240

[23] Katz, M.L. (1987) The Welfare Effects of Third-Degree Price Discrimination in Intermediate Good Markets. American Economic Review, 77, 154-167. 
[24] DeGraba, P. (1990) Input Market Price Discrimination and the Choice of Technology. American Economic Review, 80, 1246-1253.

[25] Haucap, J., Pauly, U. and Wey, C. (2001) Collective Wage Setting When Wages Are Generally Binding: An Antitrust Perspective. International Review of Law and Economics, 21, 287-307. https://doi.org/10.1016/S0144-8188(01)00061-8

[26] Haucap, J. and Wey, C. (2004) Unionisation Structures and Innovation Incentives. Economic Journal, 114, C149-C165. https://doi.org/10.1111/j.0013-0133.2004.00203.x

[27] Mukherjee, A. (2008) Unionised Labour Market and Strategic Production Decision of a Multinational. Economic Journal, 118, 1621-1639. https://doi.org/10.1111/j.1468-0297.2008.02183.x

[28] Layard, R., Nickell, S. and Jackman, R. (1991) Unemployment, Macroeconomic Performance and the Labour Market. Oxford University Press, Oxford. 